\title{
What Determines the Location Choice of R\&D Activities by Multinational Firms?
}

\author{
Iulia Siedschlag ${ }^{\mathrm{a}, \mathrm{b}, *}$, Donal Smith ${ }^{\mathrm{c}, \mathrm{d}}$, Camelia Turcu ${ }^{\mathrm{e}}$, Xiaoheng Zhang ${ }^{\mathrm{a}, \mathrm{b}}$ \\ ${ }^{a}$ The Economic and Social Research Institute, Dublin, Whitaker Square, Sir John \\ Rogerson's Quay, Dublin 2, Ireland \\ ${ }^{b}$ Department of Economics, Trinity College Dublin, Ireland \\ ${ }^{c}$ Department of Finance, Government Buildings, Upper Merrion Street, Dublin 2, \\ Ireland \\ ${ }^{d}$ Department of Economcs and Related Studies, University of York, York, United \\ Kingdom \\ ${ }^{\mathrm{e}}$ University of Orléans, Rue de Blois, BP 6739, 45067 Orléans Cedex 2, France \\ *Corresponding author: iulia.siedschlag@esri.ie Tel. +353-1-8632116
}

\begin{abstract}
We analyse 446 location decisions of $R \& D$ activities by multinational firms incorporated in the European Union over 1999-2006. Our results suggest that on average, the location probability of a representative $R \& D$ foreign affiliate increased with agglomeration economies from foreign R\&D activities, human capital, proximity to centres of research excellence and the research and innovation capacity of the region. Further, our evidence suggests that in comparison to European multinational firms, the effects of patents intensity and proximity to centres of research excellence were stronger in the case of North American multinational firms. While government $R \& D$ expenditure intensity increased the probability of location of $R \& D$ activities by European multinational firms in the region, it did not have a significant effect on the probability of location of R\&D activities by North American multinational firms.
\end{abstract}

JEL classification: F23; O32; R38

Key words: $\quad$ Foreign direct investment; Internationalisation of R\&D; Location choice; Conditional logit models; Nested logit models; European Union. 


\section{$1 \quad$ Introduction}

There has been a growing internationalisation of enterprise $R \& D$ activities over the last two decades. Multinational enterprises (MNEs) are the main drivers of this growing internationalisation of enterprise $R \& D$ and in many countries foreign affiliates carry out more R\&D than domestic firms (OECD, 2007; Abramovsky et al., 2008). While traditional cross-border R\&D enterprise activities have tended to locate in developed economies, an increasing amount of $\mathrm{R} \& \mathrm{D}$ outward investment in recent years has gone to emerging economies (OECD, 2007; European Commission, 2008; Sachwald, 2008). The type and motivations of R\&D investment vary depending on whether R\&D activities by multinationals were located in developed or emerging economies (Thursby and Thursby, 2006; Shimizutani and Todo, 2008; Sachwald, 2008).

In recent years, the speed and extent of the internationalisation of $R \& D$ have increased (von Zedtwitz and Gassmann, 2002; UNCTAD, 2005; Abramovsky et al., 2008). This increased mobility of $R \& D$ and innovation activities has been linked to increased global competition, technological change, in particular the use of information and communication technologies (ICT) and the availability and costs of skills (Abramovsky et al., 2008, OECD, 2008). In addition to the traditional role of R\&D foreign investment in diffusing technology (demand-driven) related to adapting products and services to local market conditions and supporting MNEs local manufacturing operations, $\mathrm{R} \& \mathrm{D}$ foreign investment is being increasingly motivated by tapping into worldwide centres of knowledge (supply-driven) as part of firms strategies to source innovation globally (Wortmann, 1990; Hakanson and Nobel, 1993; Florida and Kenney, 1994; Florida, 1997; Patel and Vega, 1999; Le Bas and 
Sierra, 2002; Iwasa and Odagiri, 2004; von Zedwitz and Gassmann, 2002; Ambos, 2005; Abramovsky et al. 2008; OECD, 2008).

Over the period 1995-2005, the share of foreign affiliates in total business R\&D expenditure has increased substantially in almost all European Union's countries (European Commission, 2008). In 2005, this share was over 70 per cent in Ireland, over 50 per cent in Belgium and the Czech Republic, over 40 per cent in Austria and Sweden. In contrast, the share of R\&D expenditure by foreign affiliates was lower, less than 25 per cent in Slovakia and Finland. The European Union (EU) is the largest recipient of R\&D investment by US multinationals. In 2005, the EU accounted for 62.5 per cent of the R\&D expenditure of affiliates of US parent companies abroad. Abramovsky et al. (2008) show that in comparison to 1990, over the period 20002004, the average level of innovative activity of multinational firms from EU countries located abroad grew faster than their innovative activity conducted in the home country. This dynamics has lead to a growing share of the innovative activity located abroad in the total innovative activity of multinational firms.

This increasing internationalisation of R\&D activity in the EU raises a number of questions which are interesting and relevant for both research and policy making: Where are the R\&D activities of multinational enterprises located? Who are the main foreign investors in R\&D activity? What factors drive the location choice of multinational R\&D activity?

To answer these questions, we analyse the determinants of the location choice of R\&D activities by multinational firms across regions in the European Union. By considering regions as location choices we account for heterogeneity of locations within countries and avoid the aggregation bias which might arise when using country 
averages in cross-country analyses. We use a large firm-level data set ${ }^{1}$ which enables us to consider a wide range of location choices of $\mathrm{R} \& \mathrm{D}$ activities by multinational firms. Specifically, we analyse the location choice of R\&D activities of 446 new foreign affiliates incorporated in the European Union over the 1999-2006 period. The large number of location choices (233 regions) enables us to obtain robust estimates of determinants of the attractiveness of regions to foreign investment in $R \& D$ activity. $^{2}$

The traditional theory of multinational firms has modelled the location decision of multinational firms assuming that $R \& D$ activity is located where production takes place and it has not addressed specifically the case of the location choice of R\&D activities by multinational firms. ${ }^{3}$ Notable exceptions are Markusen (2002) and Ekholm and Hakkala (2007). These latter theoretical contributions allow the geographical separation of knowledge-based (R\&D) activities and production facilities in a two-country general equilibrium setup. The theoretical model proposed by Markusen (2002) known as the "knowledge capital model” of multinationals firms predicts that when trade costs are low, international production is likely to locate in large economies while knowledge-intensive activities will concentrate in small skillsintensive economies. The model developed by Ekholm and Hakkala (2007) allows agglomeration forces to arise in both production and R\&D activities and predicts that international production will locate in a larger economy while $R \& D$ activities by multinationals will locate in a smaller economy to benefit from R\&D spillovers.

\footnotetext{
${ }^{1}$ The Amadeus data set provided by Bureau van Dijk contains information on over 18 million firms located in 43 countries in Europe. We discuss in more detail our data in Section 3.

${ }^{2}$ Data on regions is taken from the Regio data set of the Eurostat and the European Regional Database provided by Cambridge Econometrics. We discuss in more detail these data in Section 3.

${ }^{3}$ For reviews of this literature see Fujita et al. (1999) and Markusen (2002).
} 
In contrast to the slow development of the theoretical literature on the location choice of R\&D activities by multinational firms, a growing number of empirical studies have analysed the internationalisation of $\mathrm{R} \& \mathrm{D}$ and the development of $\mathrm{R} \& \mathrm{D}$ global networks (Florida and Kenney, 1994; Patel and Vega, 1999; Frost, 2001; Ambos, 2005; Abramosvsky et al. 2008; Sachwald, 2008).

Given that multinational enterprises are concentrated in R\&D-intensive industries, many factors driving the location choice of foreign affiliates are also relevant and important in the case of R\&D activities of multinationals. However, as documented in a number of recent studies in international business, in addition to demand-side factors, such as market access, factors specific to the R\&D sector such as knowledgesourcing have become increasingly important as a motivation for establishing $R \& D$ units abroad (Florida, 1997; Patel and Vega, 1999; Frost, 2001; Le Bas and Sierra, 2002; von Zedtwitz and Gassmann, 2002; Ambos, 2005; Ito and Wakasugi, 2007; Belderbos et al. 2008). Most existing studies analyse determinants of the location choice of foreign R\&D in a single country setup. Cantwell and Iammarino (2000) analyse the location patterns of multinational networks for innovation in the UK regions. Frost (2001) examines the origin of external sources of innovation of US greenfield subsidiaries. Ito and Wakasugi (2007) and Shimizutani and Todo (2008) investigate determinants of Japanese R\&D investments abroad and Iwasa and Odagiri (2004) analyse determinants of Japanese R\&D investment in the US. Ambos (2005) analyses motivations of German-owned multinational enterprises with international R\&D activities.

This paper builds on and extends these two strands of literature, namely the existing theoretical and empirical literatures, on international trade and investment on one hand, and on the internationalisation of $R \& D$ and global $R \& D$ networks on the other 
hand. We add to the empirical literature on the location choice of multinational enterprises in three ways. First, in contrast with most existing empirical studies mentioned above which consider both demand-driven (market access) and supplydriven (knowledge sourcing) motivations for foreign direct investment in $R \& D$ in a single country setup, we estimate location choice models in a multi-country setup. Second, in contrast to existing cross-country analyses, we account for heterogeneity of locations within countries and avoid aggregation bias in the estimates of the location choice determinants. Third, in contrast to previous studies, we use an improved econometric methodology to account for spatial correlation among location alternatives and firms due to unobserved location-specific characteristics.

Our results suggest that on average, the probability to locate in an EU region increased with agglomeration economies from foreign R\&D activities, human capital, proximity to centres of research excellence and the research and innovation capacity of regions. There is also evidence of a geographical structure in the location choice of R\&D multinational firms across the European Union. Further, our evidence suggests that in comparison to European multinational firms, the effects of patents intensity and proximity to centres of research excellence were stronger in the case of North American multinational firms. While government R\&D expenditure intensity increased the probability of location of R\&D activities by European multinational firms it had no significant effect on the location of R\&D activities by North American multinational firms.

The remainder of this paper is organised as follows. Section 2 describes the empirical methodology and testable hypotheses. Section 3 presents our data and summary statistics. The results of our econometric analysis are presented in Section 4. Finally Section 5 summarises our results and concludes. 


\section{$2 \quad$ Empirical Methodology}

\subsection{Modelling Location Choice}

The background for our analytical framework is the literature on the behaviour of multinational firms (Dunning, 1977, 1981; Cantwell, 1994; Krugman, 1991; Horstmann and Markusen, 1992; Markusen, 1995). This literature models a multinational firm's location decision as part of a three-step decision-making process which starts with the firm's decision to serve a foreign market and follows with the choice to undertake foreign direct investment and the location choice. This analytical convention is discussed in more details by Devereux and Griffith (1998), Head and Mayer (2004) and Basile et al. (2008). In the first stage, a firm decides whether to enter a foreign market. Following the decision to enter foreign markets, the next step is the choice on whether to enter foreign markets by exporting or by foreign direct investment. If foreign direct investment is the chosen option to enter foreign markets, the firm decides where to locate. Devereux and Griffith (1998) model the location choice of multinational firms as well as the options of not serving the foreign markets and of exporting as a mode to enter a foreign market. Head and Mayer (2004) and Basile et al. (2008) focus on the determinants of the location choice of international production by multinational firms.

In this paper, we focus on the last step of this process and use two discrete choice models to analyse the determinants of the location choice of $R \& D$ activities by multinational firms. First, we estimate a conditional logit model following McFadden (1974) which we use as a benchmark for our analysis. This model has been widely used for spatial choice analysis as it allows the modelling of a decision with more than two discrete outcomes (Haynes and Fotheingham 1990). This random utility maximization model assigns a utility level $U_{i j}$ to each alternative $j=1, \ldots . ., N$ for 
each decision maker $i=1, \ldots . . I$ for vectors of observed attributes (McFadden 1974). For each firm $\mathrm{i}$ the utility from locating in a given region $\mathrm{j}$ depends on a deterministic component $X_{i j}$ which is a function of the observed characteristics and some unobservable factors which are captured by a stochastic term $\varepsilon_{i j}$ :

$$
U_{i j}=X_{i j}^{\prime} \beta+\varepsilon_{i j}
$$

The probability that a firm i chooses to start up a plant in a region $\mathrm{j}$ as opposed to any other region $\mathrm{k}$ is then equal to the probability of $U_{i j}$ being the largest of all $U_{i 1}, \ldots . ., U_{i J}$ (Heiss 2002).

To estimate equation (1) an assumption must be made about the joint probability distribution of the unknown stochastic utilities $\varepsilon_{i j}$. As shown by McFadden (1974) under the assumption of independently and identically distributed (IID) error terms with type 1 extreme value (Gumbel) distribution, the probability of choosing a location h is:

$$
P(y=h \mid 1, \ldots, J)=\frac{e^{\beta X_{i h}}}{\sum_{j=1}^{J} e^{\beta X_{i j}}}
$$

The IID assumption on the error terms implies a statistical property in the conditional logit model, the independence of irrelevant alternatives (IIA). This property states that the relative probability ratio (the odds ratio) of any alternative being chosen over another alternative is independent of the size and composition of the choice set of alternatives. With IID, the error terms cannot contain any alternative-specific information and so adding a new alternative cannot alter existing relationships between pairs of alternatives. This assumption thus constrains the ratios to be constant over all possible choice sets. This imposes a rigid substitution pattern across all 
alternatives as for the odds ratio to remain constant as alternatives are added and removed from the choice set, the individual choice probability of the remaining alternatives will have to change by the same amount (Hunt 2004). If the model's IIA property is violated, this will lead to biased parameter estimates. As discussed in Haynes and Fotheingham (1990), the equal substitution pattern implied by the IIA property is unlikely to hold in a spatial choice framework due to location-specific characteristics of size, aggregation, dimensionality, continuity and variation. These characteristics may yield alternatives spatially correlated in unobservable factors and so estimates will be biased.

To account for this, a nested logit model is used. The nested structure is created by grouping the alternative locations choices into nests chosen according to the degree of similarity and so correlation between the alternatives (Basile et al 2003). Therefore in the location choice model, the nests consist of regions with similar characteristics, hence correlation is allowed within but not across nests. The structure allows the independence of irrelevant alternatives (IIA) property to hold within nests but not across nests.

Following Heiss (2002), let the error term to follow a generalised extreme value distribution. Denote $\tau_{k}=\sqrt{1-\rho_{k}}$, where $\rho_{k}$ is the correlation of alternatives in nest $k$, thus $\tau_{k}$, the inclusive value (IV) parameter, measures the independence of alternatives in nest $k$. If $\tau_{k}=1$, the alternatives are perfectly independent of each other and so there the nested structure is not required. At this value of the IV parameter the nested model collapses into the conditional logit model. If $\tau_{k}=0$, perfect dependence exists and as the alternatives are perfect substitutes, the nest then 
becomes the alternative. One can further write the log sum of utilities generated from alternatives in nest $k$ as follows:

$$
I V_{k}=\ln \sum_{j \in n_{k}} \exp \left(U_{i h} / \tau_{k}\right)
$$

$I V_{\mathrm{k}}$ is the inclusive value of nest $k$ (denoted by $n_{k}$ ). Therefore, $\tau_{k}$ is the IV parameter of $n_{k}$. The probability function of alternative $h$ in nest $k$ being chosen is the product of the probability of choosing nest $k(\operatorname{Pr}(k))$ and the conditional probability of choosing $h$ given that $k$ is chosen $(\operatorname{Pr}(h \mid k))$. The function can be expressed as follows:

$$
\operatorname{Pr}(y=h \mid 1, \ldots, J)=\operatorname{Pr}(h \mid k) \operatorname{Pr}(k)=\frac{\exp \left(U_{h} / \tau_{h}\right)}{\exp \left(I V_{h}\right)} \frac{\exp \left(\tau_{h} I V_{h}\right)}{\sum_{K} \exp \left(\tau_{k} I V_{k}\right)},
$$

where $\tau_{h}$ and $I V_{h}$ are the IV parameter and the inclusive value for the nest where alternative $h$ is in.

The choice of possible nested structures is multiple and there is no systematic way to identify a best structure amongst all possible nests (Greene and Hensher 2002). However, for the nested model to be consistent with the Random Utility Maximisation (RUM) framework - the IV parameter $\tau_{k}$ s has to be bounded between 0 and 1 (Heiss 2002).

\subsection{Testable Hypotheses and Model Specifications}

The dependent variable $\left(y_{i j}\right)$ is the location choice of each R\&D activity of a new foreign affiliate over 233 possible locations. ${ }^{4}$ Specifically, the dependent variable is a

\footnotetext{
${ }^{4} 233$ NUTS 2 regions in the European Union (EU-27) countries having at least one R\&D foreign affiliate and for which data on regional characteristics are available.
} 
binary variable equal to one if firm i located in region j over the period 1999 to 2006 and zero for all regions different from $\mathrm{j}$.

$y_{i j}=\left\{\begin{array}{ll}1 & \text { if } \pi_{i j}>\pi_{i k}, \forall j \neq k \\ 0 & \text { otherwise }\end{array}\right\}$

$\pi_{i j}$ is the expected profit for firm i in region $\mathrm{j}$. Since $\pi_{i j}$ is not observed we estimate it as a function of variables that are likely to influence it.

Each firm's location decision is explained as being a function of regional characteristics as well as policy variables at national level. The empirical analysis of the location choice of multinational enterprise activity distinguishes between horizontal and vertical motivations of foreign direct investment (Mayer et al. 2007). Horizontal motivations are driven by market access and market potential of an area and affect the revenue component of the profit function. Vertical motivations are concerned with the firms' cost, locating the firm and its affiliates in regions that will minimize the cost element of the profit function. The literature on the internationalisation of $R \& D$ suggests that knowledge-sourcing has become an important motivation for establishing R\&D activities abroad (Florida, 1997; Frost, 2001; von Zedtwitz and Gassmann, 2002; Ambos, 2005; Ito and Wakasugi, 2007; Belderbos et al., 2008). The importance of various motivations for the location of R\&D activities as well as the type of investment vary depending on whether those locations were in developed or emerging economies. Thursby and Thursby (2006) document on the basis of the results of a survey of over 200 multinationals across 15 industries that the most important motivations for the location choice of $R \& D$ activities by multinationals in the advanced economies were the quality of R\&D personnel, the quality of intellectual property protection and the ease of collaborating with universities, while the growth of market potential, the quality of R\&D personnel 
and the cost of research were the most important motivations in the case of locating R\&D activities in emerging economies. Shimizutani and Todo (2008) distinguish between research and development/design activities of Japanese subsidiaries abroad and find that while both research and development/design activities are performed in advanced economies, in emerging economies most of $R \& D$ activities by Japanese multinationals are development/design activities. Further, while R\&D expenditure intensity had a positive impact on the location of research activities, the knowledgeintensity of the parent firm had a positive effect on the location choice of development/design activities. It appears that while advanced knowledge-sourcing from the host country is the primary objective of research activities, adapting products and technology to local conditions drives the location of development/design activities by multinational firms.

For horizontal motivations, the location and demand size of the final consumer market are important (Krugman, 1980). This is important in the case of $R \& D$ activities as by far the most common form of overseas R\&D facility is the support laboratory. The purpose of these facilities is to adapt technologies and products to local markets and also provide technical backup for local manufacturing and sales (Dicken 2004; Shimitzutani and Todo, 2008). However, as shown by Motta (1992) and Neary (2002) this relationship between market size and foreign direct investment is not monotonic as market size also affects the number and so competition between firms.

Following Harris (1954), we measure market potential of each host region by GDP in that region and a distance-weighted sum of GDP in all other regions ${ }^{5}$. In theory, the effect of market potential on the probability to locate in a region is ambiguous.

\footnotetext{
${ }^{5}$ The argument made by Harris (1954) is that, in a multicounty set up, the actual demand which firms face in a given location is determined in addition to the size of local market by the sum of the market
} 
Agglomeration economies from foreign $R \& D$ activities are likely to be of particular importance as R\&D activities are characterised by the need to assemble a diverse and skilled network of workers, sophisticated infrastructure and also uncertainty surrounding outcomes. This leads to a need to concentrate activities (Dicken 2004). This effect can be negative as agglomeration diseconomies, due to resources such as labour being bid up in the region (Head et al. 1999). Firm-specific agglomeration occurs as it reduces the uncertainty of operating in a region and so reduces the risk of new investments. ${ }^{6}$ To account for this spatial dependence, we measure agglomeration by the number of R\&D foreign affiliates in the same region plus a distance-weighted ${ }^{7}$ measure taking into account foreign-owned R\&D firms located in all other regions. Firms are counted at the beginning of the period to mitigate endogeneity problems. As pointed out by Head and Mayer (2004), counts of multinational firms also proxy the unobserved attractiveness of regions to foreign direct investment and thus alleviate the omitted variable bias.

As for vertical motivations, a number of factors are considered important in determining the costs of production such as labour costs, unemployment rates (a proxy for labour market flexibility), and taxation.

We proxy labour costs with compensation per employee in each region. The expected effect can be positive or negative. While regions with high labour costs can indicate the presence of highly skilled workers, regions with low labour costs would be associated with low skills. It is thus necessary to account for human capital. We use

sizes of the neighbouring regions weighted by a measure of accessibility to all regions. For a discussion of measuring market potential in modelling the location choice of multinational firms see Crozet et al. (2004) and Altomonte (2007).

${ }^{6}$ Barry et al. (2003) provide empirical evidence showing that the presence of multinational firms in Ireland has acted as a "demonstration effect" for the attraction of new foreign direct investment.

${ }^{7}$ Distance is measured by estimated road - freight travel time in hours between capital cities of regions. We thank Matthieu Crozet for providing us with these estimates. The data used and estimation methodology are described in Brülhart et al (2004). 
the percentage of the economically active population with tertiary education as a proxy for human capital in a region indicating a more productive labour force. Our theoretical prior is a positive effect of human capital on the location probability.

The effect of the unemployment rate on the location probability is ambiguous. On one hand, as shown in efficiency wage models, unemployment reduces workers bargaining power and increases worker effort as it increases the cost of being fired. On the other hand, high unemployment can indicate a pool of available labour but may also be related to labour market rigidities in a region.

Tax directly reduces the profits of firms. Devereux and Griffith (1998) show that the effective average corporate tax rates significantly influence US multinational firms' decision on which European country to locate in. Tax rates can also indicate a stock of public goods and so the sign may be positive. Benassy - Quéré et al (2000) show that firms may be willing to pay higher taxes in exchange for more public goods. To control for the effect of taxation on the location probability of R\&D activities of multinational firms we use data on the top corporate tax rate at country level. ${ }^{8}$

A growing number of countries use R\&D fiscal incentives ${ }^{9}$ to increase the level of R\&D investment. However, R\&D tax incentives can foster as well as discourage international investment. To the extent that many firms prefer to incur $R \& D$ costs where they can be offset against higher taxes, countries with lower corporate tax rates might be less attractive to foreign R\&D investment (OECD, 2002, 2009). Hall and van Reenen (2000) survey existing econometric evidence from country studies and

\footnotetext{
${ }^{8}$ We use data on corporate tax rates available from the World Tax database available from the Michigan Business School, http://www.bus.umich.edu/otpr/otpr/default.asp

${ }^{9}$ Among OECD countries, 26 governments use R\&D fiscal incentives to promote business R\&D investment. Government R\&D tax incentives include R\&D tax credits, R\&D allowances, reductions in R\&D workers' wage taxes and social security contributions, and accelerated depreciation of capital used for R\&D (OECD, 2011).
} 
conclude that R\&D investment is responsive to R\&D tax credits. Bloom et al (2002) analyse a panel data on tax changes and R\&D expenditure in nine OECD countries over the period 1979-1997 and find that on average, R\&D tax credits had a significant positive effect on the level of $R \& D$ investment in the short-run as well as in the longrun. While controlling for the tax treatment of $R \& D$ is desirable, for the purpose of this paper, data on $R \& D$ tax incentives is not available for a sufficient number of countries and years. ${ }^{10}$

The literature on the internationalisation of R\&D (Wortmann, 1990; Hakanson and Nobel, 1993; Almeida, 1996; Daniels and Lever 1996; Florida 1997; Patel and Vega, 1999; Cantwell and Iammarino, 2000; Kumar, 2001; Le Bas and Sierra, 2002; von Zedtwitz and Gassmann 2002; Dicken 2004; Iwasa and Odagiri, 2004; Ambos, 2005; Ito and Wakasugi, 2007; OECD 2008) points to access to a strong knowledge base as a factor driving foreign investment in the $R \& D$ sector. To test this effect on the location choice of R\&D activities by multinational firms, we proxy the knowledge base of regions by patent intensity, calculated for each region as the number of patent applications to the European Patent Office per GDP. ${ }^{11}$ Patents have been extensively used to measure innovation output and the technology capacity of regions and countries (Jaffe et al., 1993; Almeida, 1996; Cantwell and Iammarino, 2000; Frost, 2001; Iwasa and Odagiri, 2004; Abramovsky et al., 2008). However, not all firms use patents in their innovation strategy. In addition, patents measure inventions while innovation activity is broader than inventions. Therefore, alternatively we use R\&D

\footnotetext{
${ }^{10}$ Data on the rate of R\&D tax subsidies over the period 1990-2008 are available from the OECD (2007, 2009) for 12 of the 21 European Union countries analysed in this paper.

${ }^{11}$ We also consider the following additional measures of patent intensity at regional level available from the Regional Statistics database of the Eurostat: the number of patent applications to the European Patent Office (EPO) per labour force; the number of patent applications to the EPO per employees; the number of patent applications per inhabitants. Each of these measures are highly correlated with the market potential measure (pair-wise correlations were around 0.67 ) and we do not use them in regressions.
} 
expenditure intensity, which has been also extensively used to proxy innovation activity and the level of technological development (Kumar, 2001; Shimituzani and Todo, 2008). Specifically, we use three measures of R\&D expenditure intensity: total $R \& D$ expenditure, business $R \& D$ expenditure and government $R \& D$ expenditure as a percentage of regional GDP. Our theoretical prior is a positive link between the innovation and technological capacity of the region measured alternatively by patent intensity and $R \& D$ expenditure intensity and the location probability of $R \& D$ activities by multinational firms.

Florida and Kenney (1994) have shown that an important number of Japanese R\&D subsidiaries in the US are located near major research centres to access new sources of scientific and technological excellence. Abramovsky et al (2007) find that foreignowned $R \& D$ labs are located in the proximity of centres of university research excellence in the UK. Universities provide firms with access to high quality researchers for basic scientific research. Location close to universities indicates that R\&D firms are engaging in a higher level of research than a basic production support function and are engaging in global market orientated R\&D (Dicken 2004). Thursby and Thursby (2006) document the growing role of universities in global innovation systems. This result comes out from a survey of over 200 multinational firms on the factors that influence the decisions on the location of R\&D. Proximity to universities ranks higher than costs factors in developed countries and it is as important as cost factors in emerging economies. To capture the effect of proximity to centres of research excellence, we include a dummy variable which is equal to one if a region has at least one university ranked in the top 500 ranked universities ${ }^{12}$. We test the

\footnotetext{
${ }^{12}$ We use the QS World University Ranking published annually available from http://www.topuniversities.com/university-rankings/world-university-rankings
} 
hypothesis that the presence of a top ranked university in the region is positively associated with the location choice of R\&D foreign affiliates.

In this paper we focus on long-term determinants of the location choice of new R\&D foreign affiliates and we do not consider firms decisions to exit markets. In the latter case, an analysis using panel data would be more suitable. ${ }^{13}$

Explanatory variables are lagged with respect to the dependent variable to account for the fact that investment decisions are lagged in time and to avoid possible endogeneity. Detailed variables definitions and data sources are given in Table A1 in the Appendix.

\section{Data and Summary Statistics}

The firm-level data used in this analysis is taken from the Amadeus database provided by Bureau van Dijk ${ }^{14}$, which contains information on over 18 million firms located in 43 European countries. By using data over the period 1999-2006 on ownership, location, incorporation date and industry affiliation, we identify 446 newly established R\&D activities by multinational firms in EU regions. A firm is defined as foreignowned if it had one foreign shareholder with at least 10 per cent of voting share in it. This definition is in line with the IMF's definition of "foreign direct investment enterprise” (IMF 1993). Thus, we identify 3,5 million foreign affiliates which fulfil this definition. We extract data on R\&D activities by multinational firms from the database according to NACE Rev. 1.1 codes $^{15}$. R\&D activities are classified as K73.

\footnotetext{
${ }^{13}$ Becker et al (2005) discuss this point.

${ }^{14}$ Information about the Amadeus database is available from http://bvdinfo.com/Products/CompanyInformation/International/AMADEUS.aspx

${ }^{15}$ NACE is the European Communities statistical classification system for economic activities.
} 
The identified 446 new R\&D activities by multinational firms over the period 19992006 are located in 233 regions $^{16}$ in 21 EU countries. ${ }^{17}$ The location choice is analysed at regional level as multinational firms consider both country and region characteristics in their decision. Regional data are taken from the Eurostat and the European Regional Database provided by Cambridge Econometrics. ${ }^{18}$

Table 1 about here

Table 1 presents descriptive statistics of the locations of new $R \& D$ activities by multinational firms over the analysed period, 1999-2006. Columns one and two show the top ten countries chosen as location of the new R\&D foreign affiliates. Regions in the United Kingdom and Germany attracted the bulk of foreign investment in R\&D, approximately 72 per cent of the total number of R\&D foreign investments. Six per cent of the new firms chose regions in the new EU countries. Column three shows the top ten countries after the number of new R\&D foreign investments per GDP. Romania attracted the largest number of $R \& D$ foreign affiliates relative to its economic size. Column four shows that Inner London attracted the largest number of new R\&D foreign affiliates.

Table 2 provides summary statistics of the origins of the firms in our sample by broad geographical classification. 50.9 per cent of the firms in the sample originate from one

\footnotetext{
${ }^{16}$ Regions classified as NUTS 2 regions. NUTS stands for "the Nomenclature of Territorial Units for Statistics", which is a geographic coding system developed by the EU to reference administrative regions within its countries. A detailed description of the regions classified as NUTS 2 is available from Eurostat (2007)

http://epp.eurostat.ec.europa.eu/cache/ITY_OFFPUB/KS-RA-07-020/EN/KS-RA-07-020-EN.PDF

17 Austria, Belgium, the Czech Republic, Denmark, Estonia, Finland, France, Germany, Greece, Ireland, Italy, Latvia, Lithuania, the Netherlands, Poland, Portugal, Romania, the Slovak Republic, Spain, Sweden, the United Kingdom.

18 Eurostat's database containing regional statistics is available from http://epp.eurostat.ec.europa.eu/portal/page/portal/region_cities/regional_statistics/data/database Information about Cambridge Econometrics is available from http://www.camecon.com
} 
of the EU-15 countries ${ }^{19}$, Switzerland or Norway. As for individual countries the top origin country is the United States accounting for 30.7 per cent followed by Switzerland with 9.6 per cent of the number of new R\&D foreign affiliates.

Table 3 presents summary statistics of the explanatory variables used in our empirical analysis.

Table 3 about here

Regional characteristics vary in particular with respect to agglomeration economies from foreign R\&D activities, human capital and compensation per employee. Table 4 shows pair-wise correlations among all explanatory variables.

Table 4 about here

Total R\&D expenditure intensity is highly correlated with business R\&D expenditure intensity (0.9678) which indicates a high share of business $R \& D$ expenditure in total R\&D expenditure. Patents intensity appear correlated with business $R \& D$ expenditure intensity (0.6585) and with total R\&D expenditure intensity (0.6447). To account for these high correlations we will use patents intensity and R\&D expenditure intensity in separate regressions. We also check the sensitivity of our estimates to potential bias from high correlations between market potential and compensation per employee (0.5910), market potential and patents intensity (0.5931), compensation per employee and patents intensity (0.5128).

\footnotetext{
${ }^{19}$ Austria, Belgium, Denmark, Finland, France, Germany, Greece, Ireland, Italy, Luxembourg, the Netherlands, Portugal, Spain, Sweden, and the United Kingdom.
} 


\section{$4 \quad$ Econometric Results}

\subsection{Conditional Logit Models}

Table 5 shows the estimates of the conditional logit models. The first three columns show the results obtained for newly established R\&D activities by all multinational firms over all regions. The first column shows the model with patent intensity as a proxy for the innovation capacity of regions. Column two shows the estimates obtained without compensation per employee and patent intensity which appear correlated with market potential. In this case we use total $R \& D$ intensity to proxy the innovation capacity of regions. In column three we use compensation per employee as a proxy for human capital and use business and government $R \& D$ expenditure intensity to proxy the knowledge base of regions. The figures reported are the average probability elasticities (APE). ${ }^{20}$ The reported standard errors are clustered at countrylevel. $^{21}$

Table 5 about here

It appears that on average, other things equal, the probability to locate $R \& D$ activities of foreign affiliates across regions in the EU was associated positively with agglomeration economies from foreign $R \& D$ activities. This result indicates that the benefits of clustering R\&D activity outweigh any local competition effects. This variable is also an indicator of positive unobserved characteristics in a region as when multinational firms locate in a region it can be taken as a signal by other firms of

\footnotetext{
${ }^{20}$ The APEs in the conditional logit models for market potential, compensation per employee, agglomeration and patent intensities are obtained as follows: $e_{x}=\beta_{x}\left(1-\frac{1}{J}\right)$ where $\beta_{x}$ is the estimated parameter for $x$ and $\mathrm{J}$ is the number of regions in the choice set. APEs for unemployment rates, corporate tax rate, human capital and $\mathrm{R} \& \mathrm{D}$ expenditure intensities are evaluated at their mean value. The marginal effect for top university implies the change in the location probability in the case of a region having an university ranked in the world top 500 universities.

${ }^{21}$ Following Moulton (1990) and Pepper (2002), in the estimated models we cluster standard errors at country level to account for possible correlation of error terms across regions within each country due to unobserved country characteristics.
} 
favourable characteristics. Furthermore, this result suggests that agglomeration effects are important over and above the spatial concentration of R\&D activity generated by demand-linkages (Head and Mayer, 2004) and are in line with the theoretical predictions of the model developed by Eckholm and Hakkala (2007). The location probability of foreign $R \& D$ activities increases with the presence of a top university in the region, as well as the region's $R \& D$ expenditure intensity. The effect of business R\&D expenditure intensity appears stronger in comparison to the effect of government R\&D expenditure intensity. The effect of the regional unemployment rate is negative but insignificant indicating that the availability of labour or the presence of labour market rigidities do not affect the attractiveness of regions to $\mathrm{R} \& \mathrm{D}$ foreign affiliates

The tax variable is not significant across all specifications. This result suggests that the corporate tax rate in a country has no significant effect on the location of $R \& D$ activities by multinationals in regions of that country over and above other determinants of the location choice. Basile et al. (2008) and Spies (2010) also find an insignificant effect of the corporate tax on the location choice of multinational firms. Regional average compensation per employee and human capital appear also insignificant. These results are consistent with Devereux and Griffith (1998).

The baseline model was estimated across all regions and firms. However it is possible that heterogeneity among firms in the treatment of regional characteristics exists and so firms may weigh regional characteristics differently. This difference in firm behaviour will not be seen when they are grouped together. To examine this possibility, the sample of foreign affiliates is divided by country of origin and we estimate the models 1-3 for European and North American multinational firms 
separately. ${ }^{22}$ Columns $4-6$ contain the estimates for European multinational firms while columns 7-9 show the estimates for North American firms. ${ }^{23}$

Agglomeration spillovers from foreign R\&D activities, the presence of a top ranked university, total R\&D expenditure intensity and business R\&D expenditure intensity were the main determinants of the location of R\&D activities by European as well as North American multinationals. The effects of agglomeration economies and proximity to centres of research excellence were stronger in the case of North American multinational firms. While government $R \& D$ expenditure intensity was associated positively and significantly with the location probability of R\&D activities by European multinationals, it did not play an important role in the case of the North American multinationals.

\subsection{Nested Logit Models}

As discussed in Section 2, estimating unbiased parameters with the conditional logit model assumes that the IIA property holds. However, given potential spatial correlation in unobservable factors, the alternative locations are unlikely to be independent in a spatial choice framework. This implies that the IIA assumption may not hold which would lead to biased estimates. We therefore test a number of geographical structures to estimate nested logit models. We find that a country-based structure was inconsistent with random utility maximization. Further, we identify a model with a four-group nesting structure to be the most successful: South, AngloSaxon, East and Central-North. The composition of this nesting structure is as

\footnotetext{
${ }^{22}$ European multinational firms are those with a parent in the following countries: Austria, Belgium, Bulgaria, Cyprus, Czech-Republic, Germany, Denmark, Spain, Finland, France, United Kingdom, Gibraltar, Greece, Ireland, Israel, Isle of Man, Italy, Liechtenstein, Luxembourg, Switzerland, Monaco, Netherlands, Norway, Poland, Portugal, Sweden. North American multinational firms are those with a parent in the US and Canada.

${ }^{23}$ Data on industrial sectors and technology fields of the R\&D activities is not available to us. Also, another limitation of our data is that we cannot distinguish between research for development and fundamental research activities.
} 
follows: South: all NUTS 2 regions in Italy, Greece, Portugal and Spain; AngloSaxon: all NUTS 2 regions in the United Kingdom and Ireland; East: all NUTS 2 regions in the Czech Republic, Estonia, Hungary, Lithuania, Latvia, Poland, Romania, and the Slovak Republic; Central and North: all NUTS 2 regions in Austria, Belgium, Denmark, Finland, France, Germany, the Netherlands and Sweden. The results from the nested logit models using this four-group geographical structure are presented in Table 6.

Table 6 about here

The IV parameters are all between zero and one, which indicates that the chosen geographical structure is valid and that choices are geographically nested. Across all specifications, the IV parameters for "South" are lower in comparison to the other three nests suggesting that the regions in "South" are perceived as more closely substitutable than the regions within the other three nests.

The Likelihood Ratio (LR) test rejects the null hypothesis of the IIA. Columns 1-3 show the results for all multinational firms, columns 4-6 for European multinational firms and columns 7-9 for North American multinational firms. Figures shown are marginal effects (average probability elasticities). ${ }^{24}$ Standard errors are clustered at country level. The average probability elasticity for market potential is positive and significant at ten percent in the model estimated for all multinationals without compensation per employee and patent intensity and it is not significant in the other eight models. Agglomeration economies from foreign R\&D activities appear to be

\footnotetext{
${ }^{24}$ The average probability elasticity with respect to the variable $x$ in the nested logit models is calculated as follows: $\bar{e}_{x}=\frac{\beta_{x}}{L}\left[\sum_{K}\left(\frac{J_{n_{k}}}{\tau_{j}}-\frac{1}{\tau_{j}}\right)+K-1\right]$ where $\beta_{x}$ is the estimated parameter of variable $\mathrm{x}$; $\mathrm{L}$ is the number of regions; $\mathrm{K}$ is the number of nests; $J_{n_{k}}$ is the number of regions in the nest $n_{k} ; \tau_{j}$ is the inclusive value parameter for the nest including region $\mathrm{j}$.
} 
important within the four geographical structures for all multinational firms as well as European and North American multinationals. Furthermore, the location choice of R\&D activities by multinationals was positively associated with the knowledge base captured by human capital ${ }^{25}$, proximity to centres of research excellence, patents intensity as well as total $R \& D$ expenditure intensity. The effect of proximity to centres of research excellence was stronger in the case of North American multinational firms. While business R\&D expenditure intensity mattered in the case of European as well as North American multinationals, government R\&D expenditure intensity played an important role only in the location choice of $R \& D$ activities of European multinationals. It appears that on average, regional characteristics such as labour costs, unemployment rates and the country corporate tax rate did not play a significant role in the location choice of R\&D activities by multinational firms over and above other determinants. ${ }^{26}$ These results are in line with the findings of Thursby and Thursby (2006) who conclude that, while important, the cost of research is not a primary factor in the location choice of R\&D activities by multinational firms.

\section{$5 \quad$ Summary and Conclusions}

In this paper we estimated the determinants of the location choice of new R\&D activities by multinational firms across regions in the European Union over the period 1999-2006. With respect to methodology improvements, in addition to conditional logit models we estimated nested logit models to account for the fact that in relation to many alternative location choices, conditional logit models might lead to biased

\footnotetext{
${ }^{25}$ In the case of the North American multinationals, human capital was positive and significant in the case of the model with patent intensity and positive but insignificant in the model without compensation per employee and patent intensity.

${ }^{26}$ The APE for compensation per employee is positive and marginally significant for all multinationals in column 1. The APE for unemployment rate is negative and marginally significant for all multinational firms in column 2 and positive but only marginally significant for North American multinationals in column 7 .
} 
estimates if the location choices are not independent. In contrast to most existing cross-country analyses, we consider regions within countries as location choices and thus avoid aggregation bias in the estimates of the location choice determinants.

We find that in our spatial choice framework the independence of the location choices does not hold. Consequently we base our conclusions on the estimates of determinants of the location choice of R\&D activities by multinationals obtained with the nested logit models. We find evidence of a geographical structure in firm's location choice across the European Union. Our results suggest that on average, the probability of the location of a representative $R \& D$ foreign affiliate in an EU region increases with agglomeration economies from foreign R\&D activities and the region’s knowledge base measured by human capital, proximity to centres of research excellence, research and innovation capacity. It appears that, over the analysed period, regional characteristics such as market potential, compensation per employee and unemployment rate, had no significant effect on the attractiveness of regions to R\&D foreign investment over and above other determinants. Some of these results might be influenced by the fact that our data does not distinguish between research and development activities. Our evidence also suggests that country level corporate tax rates had no significant effect in fostering the attractiveness of regions to $R \& D$ foreign investment over and above other determinants. This result might be explained by the fact that the sensitivity of the location probability to taxation in a country/region is higher in the case of a small number of location options (Barrios et al., 2008). Also, multinationals locate foreign affiliates in more than one country and they optimize the tax on a global base. A large number of European countries have introduced $R \& D$ tax incentives to foster investment in $R \& D$ activities. Notable exceptions are Germany, Sweden, Finland, Luxembourg and Estonia. R\&D tax 
incentives can foster as well as discourage international investment. Furthermore, the benefits to firms of R\&D tax incentives are strongly linked to the overall corporate tax rates. While it is desirable to test the effects of these $R \& D$ tax incentives on the location choice of foreign $R \& D$ activities, for the purpose of this paper, data on $R \& D$ tax subsidies over 1990-2008 are available for only 12 of the 21 countries analysed in this paper.

The determinants of the location choice of R\&D foreign affiliates vary depending on the country of origin of the foreign investor. The region's innovation capacity measured by patents intensity and business R\&D expenditure intensity as well as the presence of centres of academic research excellence were important for the location choice of R\&D activities by European as well as North American multinationals. In comparison to European multinational firms, the effects of patents intensity and proximity to centres of research excellence were stronger in the case of North American multinational firms. These results suggest that in comparison to $R \& D$ activities by European multinationals, the location of $R \& D$ activities of North American multinationals in EU regions were more likely to aim at knowledgesourcing. While government $R \& D$ expenditure intensity mattered for the location choice of R\&D activities by European multinationals, it did not play a significant role in the case of the location decisions for $R \& D$ activities by North American multinationals.

Our research results suggest a number of policy implications. First, policy aiming to increase the knowledge base of regions are likely to foster the attractiveness of regions to $R \& D$ foreign investment. Second, positive externalities from clustering of R\&D foreign affiliates outweigh competition effects. Third, given the heterogeneous 
behaviour of foreign investors, differentiated policy depending on target partner countries can increase the success of such policies.

\section{Acknowledgements}

We thank Marius Brülhart, Davide Castellani, Jim Markusen, Laura Resmini, Marc Schiffbauer, the Editor, Martin Bell, two anonymous referees and participants at research presentations at the European Trade Study Group Conference in Rome, the Economic and Social Research Institute in Dublin, the Irish Economic Association Conference in Belfast, the International Workshop on "Internationalisation of R\&D" in Ankara, the Conference on "Internationalisation of Innovation into Emerging Markets” in London, the European Regional Science Association Congress in Jönköping, the French Association of Economic Sciences Congress in Paris, the International Workshop on "Global and Local Firm Linkages" at the Institute for Applied Economic Research, Tübingen, and the International Workshop on "Recent Issues in Economic Geography” in Leuven for useful comments and suggestions.

Financial support from the European Union's RTD $6^{\text {th }}$ Framework Programme (Contract no. CIT5-028818) is gratefully acknowledged.

\section{References}

Abramovsky, L., Harrison, R., Simpson, H., 2007. University research and the location of business R\&D. The Economic Journal 117, 114-141.

Abramovsky, L., Griffith, R., Macartney, G., Miller, H., 2008. The location of innovative activity in Europe. The Institute for Fiscal Studies Working Paper 08/10.

Almeida, P., 1996. Knowledge sourcing by foreign multinationals: patent citations analysis in the U.S. semiconductor industry. Strategic Management Journal, Winter Special Issue 17, 155-165.

Altomonte, C., 2007. Regional economic integration and the location of multinational firms. Review of World Economics 143 (2), 277-305. 
Ambos, B., 2005. Foreign direct investment in industrial research and development: a study of German MNCs. Research Policy 34, 395-410.

Barrios, S., Huizinga, H., Laeven, L., Nicodème, G., 2008. International taxation and multinational firm location decisions. CEPR WP 7047.

Barry, F., Görg, H., Strobl, E., 2003. Foreign direct investment, agglomerations, and demonstration effects: an empirical investigation. Review of World Economics 139 (4), 583-600.

Basile, R., Castellani, D., Zanfei, A., 2003. National boundaries and the location of multinational firms in Europe: a nested logit analysis. EMS Working Papers, University of Urbino.

Basile, R., Castellani, D., Zanfei, A., 2008. Location choices of multinational firms in Europe: the role of EU cohesion policy. Journal of International Economics 74 (2), 328-340.

Becker, S.O., Ekholm, K., Jäckle, R., Muendler, M.A., 2005. Location choice and employment decisions: a comparison of German and Swedish multinationals. Review of World Economics 141 (4), 693-731.

Belderbos, R., Lykogianni, E., Veugelers, R., 2008. Strategic R\&D location in European manufacturing industries. Review of World Economics 144 (2), 183-206.

Bénassy-Quéré, A., Fontagné, L. Lahrèche-Rèvil, A., 2000. Foreign direct investment and the prospects for tax co-ordination in Europe, CEPII Document de travail n.2000-06.

Bloom, N. R. Griffith, J. Van Reenen, 2002. Do R\&D tax credits work? Evidence from a panel of countries 1979-199 , Journal of Public Economics, 85(1), 1-31

Cantwell, J., 1994. The relationship between international trade and international production. In: Greenway, D., Winters, L. (Eds.), Surveys in International Trade. Blackwell, Oxford.

Cantwell, J., Iammarino, S., 2000. Multinational corporations and the location of technological innovation in the UK regions. Regional Studies 34 (4), 317-332.

Crozet, M., Mayer, T., Mucchielli, J.L., 2004. How do firms agglomerate? A study of FDI in France. Regional Science and Urban Economics 34, 27-54.

Brülhart, M., Crozet, M., Koenig, P., 2004. Enlargement and the EU periphery: the impact of changing market potential. The World Economy 27 (6), 853-875.

Daniels, P., Lever, W., 1996. The Global Economy in Transition. Longman, Harlow.

Devereux, M.P., Griffith, R., 1998. Taxes and the location of production: evidence from a panel of US multinationals. Journal of Public Economics 68 (3), 335367.

Dicken, P., 2004. Webs of enterprise: the geography of transnational production networks. In: Dicken, P. (Eds.), Global Shift: Reshaping the Global Economic Map in the $21^{\text {st }}$ Century. SAGE Publications, London.

Dunning, J., 1977. Trade, location of economic activity and MNE: a search for an eclectic approach. In: Ohlin, B., Hesselborn, P.O., Wijkman, P.M. (Eds.), The International Location of Economic Activity. McMillan, London, pp. 395-418. 
Dunning, J., 1981. International Production and the Multinational Enterprise. George Allen and Unwin, London.

Ekholm, K., Hakkala, K., 2007. Location of R\&D and high-tech production by vertically integrated multinationals. Economic Journal 117, 512-543.

European Commission, 2008. A More Research -Intensive and Integrated European Research Area. Science, Technology and Competitiveness Key Figures Report 2008/2009. Office for Official Publications of the European Communities, Luxembourg.

Eurostat, 2007. Regions in the European Union. Nomenclature of territorial units for statistics. NUTS 2006/EU-27. 2007 edition. Office for Official Publications of the European Communities, Luxembourg

Florida, R., Kenney, M., 1994. The globalisation of Japanese R\&D: the economic geography of Japanese R\&D investment in the United States. Economic Geography 70 (4), 305- 323.

Florida, R., 1997. The globalization of R\&D: results of survey of foreign affiliated R\&D-laboratories in the USA. Research Policy 26 (1), 85-102.

Frost, T.S., 2001. The geographic sources of foreign subsidiaries' innovations. Strategic Management Journal 22, 101-123.

Fujita, M., Krugman, P., Venables, A., 1999. The Spatial Economy: Cities, Regions and International Trade. MIT Press, Cambridge, MA.

Greene, W., Hensher, D., 2002. Specification and estimation of the nested logit model: alternative normalisations. Transportation Research Part B 36, 1-17.

Hakanson, L., Nobel, R., 1993. Foreign research and development in Swedish multinationals. Research Policy 22, 373-396.

Hall, B., J. Van Reenen, 2000. How effective are tax incentives for R\&D? A review of the evidence, Research Policy, 29(4-5), 449-469

Harris,C., 1954. The market as a factor in the localization of industry in the United States. Annals of the Association of American Geographers 64, 315-348.

Hausman, J., McFadden, D., 1984. Specification tests for the multinomial logit model. Econometrica 52 (5), 1219-1240.

Haynes, K., Fotheingham, A., 1990. The impact of space on the application of discrete choice models. Review of Regional Studies 20 (2), 39-49.

Head, K., Mayer, T., 2004. Market potential and the location of Japanese investment in the European Union. The Review of Economics and Statistics 86 (4), 959972.

Head, K., Ries, J., Swenson, D., 1999. Attracting foreign manufacturing: investment promotion and agglomeration. Regional Science and Urban Economics 29 (2), 197-218.

Heiss, F., 2002. Structural choice analysis with nested logit models. The Stata Journal 2 (3), 227-252.

Horstmann, I., Markusen, J., 1992. Endogenous market structures in international trade (natura facit saltum). Journal of International Economics 32, 109-129. 
Hunt, L., Boots, B., Kanaroglou, P., 2004. Spatial choice modelling: new opportunities to incorporate space into substitution patterns. Progress in Human Geography 28, 746-764.

International Monetary Fund, 1993. Balance of Payments Manual, 5th Edition. International Monetary Fund, Washington.

Ito, B., Wakasugi, R., 2007. What factors determine the mode of overseas R\&D by multinationals? Empirical evidence. Research Policy 36, 1275-1287.

Iwasa, T., Odagiri, H., 2004. Overseas R\&D, knowledge sourcing, and patenting: an empirical study of Japanese R\&D investment in the US. Research Policy 33, 807-828.

Jaffe, A., Trajtenberg, M., Henderson, R., 1993. Geographic localization of knowledge spillovers as evidenced by patent citations. Quarterly Journal of Economics 108 (3), 577-598.

Krugman, P., 1980. Scale economics, product differentiation and the pattern of trade. American Economic Review 70 (5), 950-959.

Krugman, P., 1991. Geography and Trade. MIT Press, Cambridge, MA.

Kumar, N., 2001. Determinants of location of overseas R\&D activity of multinational enterprises: the case of US and Japanese corporations. Research Policy 30, 159-174.

Le Bas, C., Sierra, C., 2002. Location versus home country advantages in R\&D activities: some further results on multinationals' location strategies. Research Policy 31, 589-609.

Markusen, J., 1995. The boundaries of multinational enterprises and the theory of international trade. Journal of Economic Perspectives 9 (2), 169-189.

Markusen, J., 2002. Multinational firms and the theory of international trade. MIT Press, Cambridge and London.

Mayer, T., Mejean, I., Nefussi, B., 2007. The location of domestic and foreign production affiliates by French multinational firms. Centre for Economic Policy Research Discussion Paper 6308.

McFadden, D., 1974. Conditional logit analysis of qualitative choice behaviour. In: Zarembka, P. (Eds.), Frontiers in Econometrics, Chap. 4. Academic Press, New York, pp. 105-142.

McFadden, D., 1984. Econometric analysis of qualitative response models. In: Griliches, Z., Intriligator, M.D. (Eds.), Handbook of Economics Volume II. Elsevier Science Publishers BV.

Motta, M., 1992. Multinational firms and the tariff-jumping argument: a game theoretic analysis with some unconventional conclusions. European Economic Review 36 (8), 1557-1571.

Moulton, B., 1990. An illustration of a pitfall in estimating the effects of aggregate variables on micro units. The Review of Economics and Statistics 72 (2), 334338.

Neary, P., 2002. Foreign direct investment and the single market. The Manchester School 70, 291-314. 
OECD, 2002. OECD Science, technology and Industry Outlook 2002. OECD, Paris

OECD, 2007. OECD Science, Technology and Industry Scoreboard 2007. OECD, Paris.

OECD, 2009. OECD Science, Technology and Industry Scoreboard 2007. OECD, Paris.

OECD, 2008. The Internationalisation of Business R\&D. Evidence, Impacts and Implications. OECD, Paris.

OECD, 2011. OECD Science, Technology and Industry Scoreboard 2011. OECD, Paris

Patel, P., Vega, M., 1999. Patterns of internationalisation of corporate technology: location vs. home country advantages. Research Policy 28, 145-155.

Pepper, J., 2002. Robust inferences from random clustered samples: an application using data from the panel study of income dynamics. Economic Letters 75, 341-345.

Sachwald, F., 2008. Location choice within global innovation networks: the case of Europe. Journal of Technology Transfer 33, 364-378.

Shimizutani, S., Todo, Y., 2008. What determines overseas R\&D activities? The case of Japanese multinational firms. Research Policy 37, 530-544.

Spies, J. 2010. Network and border effects: where do foreign multinationals locate in Germany?. Regional Science and Urban Economics 40, 20-32.

Thursby, J., Thursby, M., 2006. Here or there? A survey on the factors in multinational R\&D location. National Academies Press, Washington D.C.

UNCTAD, 2005. World Investment Report. Transnational Corporations and the Internationalization of R\&D. United Nations, Geneva.

von Zedtwitz, M., Gassmann, O., 2002. Market versus technology drive in R\&D internationalization: four different patterns of managing research and development. Research Policy 31 (4), 569-588.

Wortmann, M., 1990. Multinationals and the internationalization of R\&D: new developments in German companies. Research Policy 19, 175-183. 
Table 1: The location of new R\&D foreign affiliates incorporated in the EU, 1999-2006

\begin{tabular}{|c|c|c|c|}
\hline $\begin{array}{l}\text { Top ten countries } \\
\text { after the share in } \\
\text { the total number of } \\
\text { R\&D foreign } \\
\text { affiliates }\end{array}$ & $\begin{array}{l}\text { Country } \\
\text { share in } \\
\text { total } \\
\text { R\&D } \\
\text { foreign } \\
\text { affiliates } \\
(\%)\end{array}$ & $\begin{array}{l}\text { Ranking of } \\
\text { countries after } \\
\text { the number of } \\
\text { R\&D foreign } \\
\text { affiliates per } \\
\text { GDP }\end{array}$ & $\begin{array}{l}\text { Top ten NUTS } 2 \text { Regions } \\
\text { after the number of R\&D } \\
\text { foreign affiliates }\end{array}$ \\
\hline United Kingdom & 35.9 & Romania & Inner London \\
\hline Germany & 35.9 & Estonia & Oberbayern \\
\hline Austria & 4.9 & Ireland & $\begin{array}{l}\text { Berkshire, Buckinghamshire and } \\
\text { Oxfordshire }\end{array}$ \\
\hline France & 4.3 & United Kingdom & East Anglia \\
\hline Romania & 4.0 & Austria & Bucuresti - Ilfov \\
\hline Ireland & 2.7 & Bulgaria & Darmstadt \\
\hline Sweden & 2.5 & Germany & Dusseldorf \\
\hline Italy & 2.0 & Denmark & Koln \\
\hline Denmark & 1.8 & Sweden & Freiburg \\
\hline Netherlands & 1.8 & Poland & Hamburg \\
\hline
\end{tabular}

Data source: Amadeus database, Bureau van Dijk

Table 2: $\quad$ Country origin of new $R \& D$ foreign affiliates incorporated in the EU, 1999-2006

\begin{tabular}{|l|c|}
\hline \multicolumn{1}{|c|}{ Origin of Firms by Area } & $\begin{array}{c}\text { \% of total number of } \\
\text { R\&D foreign } \\
\text { affiliates }\end{array}$ \\
\hline EU 15 + Switzerland \& Norway & 50.9 \\
North America & 33.1 \\
Asia \& Australia & 8.1 \\
Rest of Europe & 3.4 \\
South \& Central America & 1.6 \\
Middle East & 1.6 \\
Africa & 1.3 \\
\hline
\end{tabular}

Data source: Amadeus database, Bureau van Dijk 


\begin{tabular}{|l|c|c|c|c|c|}
\hline \multicolumn{7}{|c|}{ Table 3: Summary Statistics } \\
\hline \multicolumn{1}{|c|}{ Variable } & $\begin{array}{c}\text { Number of } \\
\text { NUTS2 } \\
\text { regions }\end{array}$ & Mean & Std. Dev. & Min. & Max. \\
\hline Market Potential & 233 & 4.3 & 0.5 & 3.0 & 5.1 \\
\hline $\begin{array}{l}\text { Compensation Per } \\
\text { Employee }\end{array}$ & 233 & 21.3 & 10.1 & 1.5 & 43.9 \\
\hline Agglomeration & 233 & 14.0 & 34.7 & 0.0 & 371.1 \\
\hline Unemployment Rate & 233 & 9.3 & 5.0 & 2.5 & 28.0 \\
\hline Corporate Tax Rate & 233 & 33.3 & 3.7 & 18.0 & 39.0 \\
\hline Human Capital & 233 & 23.0 & 10.2 & 2.8 & 53.0 \\
\hline Top University & 233 & 0.5 & 0.5 & 0 & 1 \\
\hline Patents Intensity & 233 & 3.9 & 3.9 & 0.1 & 26.5 \\
\hline Total R\&D Intensity & 216 & 1.0 & 1.0 & 0.0 & 4.8 \\
\hline $\begin{array}{l}\text { Business R\&D } \\
\text { Intensity }\end{array}$ & 216 & 0.8 & 0.9 & 0.0 & 4.2 \\
\hline $\begin{array}{l}\text { Government R\&D } \\
\text { Intensity }\end{array}$ & 216 & 0.2 & 0.2 & 0.0 & 1.9 \\
\hline
\end{tabular}


Table 4: Correlations of explanatory variables

\begin{tabular}{|c|c|c|c|c|c|c|}
\hline & $\begin{array}{c}\text { Market } \\
\text { Potential }\end{array}$ & $\begin{array}{l}\text { Compensation } \\
\text { Per Employee } \\
\end{array}$ & Agglomeration & $\begin{array}{c}\text { Unemployment } \\
\text { Rate }\end{array}$ & $\begin{array}{l}\text { Corporate } \\
\text { Tax Rate }\end{array}$ & $\begin{array}{l}\text { Human } \\
\text { Capital }\end{array}$ \\
\hline Market Potential & 1 & & & & & \\
\hline $\begin{array}{l}\text { Compensation } \\
\text { Per Employee } \\
\end{array}$ & 0.5910 & 1 & & & & \\
\hline Agglomeration & 0.1635 & 0.1534 & 1 & & & \\
\hline $\begin{array}{l}\text { Unemployment } \\
\text { Rate }\end{array}$ & -0.3346 & -0.0994 & -0.1220 & 1 & & \\
\hline $\begin{array}{l}\text { Corporate Tax } \\
\text { Rate }\end{array}$ & 0.0111 & 0.0606 & -0.0828 & 0.1684 & 1 & \\
\hline Human Capital & 0.2866 & 0.4380 & 0.3046 & -0.0553 & -0.2853 & 1 \\
\hline Top University & 0.1907 & 0.3669 & 0.1997 & -0.1950 & -0.0243 & 0.3218 \\
\hline Patents Intensity & 0.5931 & 0.5128 & 0.1277 & -0.1758 & -0.2119 & 0.3280 \\
\hline $\begin{array}{l}\text { Total R\&D } \\
\text { Intensity }\end{array}$ & 0.3065 & 0.4374 & 0.1272 & -0.2338 & -0.1641 & 0.4150 \\
\hline $\begin{array}{l}\text { Business R\&D } \\
\text { Intensity }\end{array}$ & 0.2939 & 0.4396 & 0.1154 & -0.2570 & -0.1801 & 0.3823 \\
\hline \multirow[t]{2}{*}{$\begin{array}{l}\text { Government } \\
\text { R\&D Intensity }\end{array}$} & 0.1668 & 0.1693 & 0.0914 & 0.0150 & 0.0115 & 0.2791 \\
\hline & $\begin{array}{c}\text { Top } \\
\text { University }\end{array}$ & Patents Intensity & $\begin{array}{l}\text { Total R\&D } \\
\text { Intensity }\end{array}$ & $\begin{array}{l}\text { Business R\&D } \\
\text { Intensity }\end{array}$ & $\begin{array}{c}\text { Government } \\
\text { R\&D } \\
\text { Intensity } \\
\end{array}$ & \\
\hline Top University & 1 & & & & & \\
\hline Patents Intensity & 0.3576 & 1 & & & & \\
\hline $\begin{array}{l}\text { Total R\&D } \\
\text { Intensity }\end{array}$ & 0.3500 & 0.6447 & 1 & & & \\
\hline $\begin{array}{l}\text { Business R\&D } \\
\text { Intensity }\end{array}$ & 0.3026 & 0.6584 & 0.9678 & 1 & & \\
\hline $\begin{array}{l}\text { Government } \\
\text { R\&D Intensity }\end{array}$ & 0.3028 & 0.2137 & 0.5134 & 0.2807 & 1 & \\
\hline
\end{tabular}


Table 5: Determinants of the Location Choice of R\&D Foreign Affiliates: Conditional Logit Models

\begin{tabular}{|c|c|c|c|c|c|c|c|c|c|}
\hline \multirow[b]{2}{*}{ Variable } & \multicolumn{3}{|c|}{ All multinationals } & \multicolumn{3}{|c|}{ European multinationals } & \multicolumn{3}{|c|}{ North American multinationals } \\
\hline & (1) & (2) & (3) & (4) & (5) & (6) & (7) & (8) & (9) \\
\hline \multirow[t]{2}{*}{$\begin{array}{c}\text { Market } \\
\text { Potential } \\
\end{array}$} & 0.051 & 0.388 & 0.314 & -0.105 & 0.278 & 0.170 & 0.034 & 0.355 & 0.252 \\
\hline & $(0.783)$ & $(0.895)$ & $(0.872)$ & $(0.787)$ & $(0.879)$ & $(0.860)$ & $(0.781)$ & $(0.769)$ & $(0.867)$ \\
\hline \multirow[t]{2}{*}{$\begin{array}{l}\text { Compensation } \\
\text { Per Employee }\end{array}$} & -0.101 & & 0.291 & -0.114 & & 0.342 & 0.173 & & 0.375 \\
\hline & $(0.603)$ & & $(0.595)$ & $(0.629)$ & & $(0.639)$ & $(0.586)$ & & $(0.456)$ \\
\hline \multirow[t]{2}{*}{ Agglomeration } & $0.011^{* * *}$ & $0.009 * *$ & $0.010^{* * *}$ & $0.010^{* * *}$ & $0.007^{*}$ & $0.008 * *$ & $0.012 * * *$ & $0.011^{* * *}$ & $0.011^{* * *}$ \\
\hline & $(0.002)$ & $(0.004)$ & $(0.004)$ & $(0.002)$ & $(0.004)$ & $(0.004)$ & $(0.002)$ & $(0.004)$ & $(0.003)$ \\
\hline \multirow[t]{2}{*}{$\begin{array}{c}\text { Unemployment } \\
\text { Rate }\end{array}$} & -0.047 & -0.309 & -0.346 & 0.121 & -0.199 & -0.226 & -0.410 & -0.430 & -0.524 \\
\hline & $(0.102)$ & $(0.064)$ & $(0.065)$ & $(0.094)$ & $(0.061)$ & $(0.063)$ & $(0.116)$ & $(0.068)$ & $(0.074)$ \\
\hline \multirow[t]{2}{*}{$\begin{array}{c}\text { Corporate Tax } \\
\text { Rate } \\
\end{array}$} & -0.132 & 0.727 & -0.165 & 0.430 & 1.605 & 0.301 & -1.124 & -0.760 & -1.024 \\
\hline & $(0.075)$ & $(0.078)$ & $(0.078)$ & $(0.071)$ & $(0.078)$ & $(0.075)$ & $(0.081)$ & $(0.064)$ & $(0.085)$ \\
\hline \multirow[t]{2}{*}{ Human Capital } & 0.393 & 0.531 & & 0.485 & $0.710^{* *}$ & & 0.162 & 0.255 & \\
\hline & $(0.017)$ & $(0.017)$ & & $(0.016)$ & $(0.014)$ & & $(0.028)$ & $(0.028)$ & \\
\hline \multirow[t]{2}{*}{ Top University } & $0.554 * * *$ & $0.539 * * *$ & $0.527 * * *$ & $0.448^{* *}$ & $0.529 * * *$ & $0.505^{* *}$ & $0.694 * * *$ & $0.788^{* * *}$ & $0.785^{* * *}$ \\
\hline & $(0.281)$ & $(0.239)$ & $(0.288)$ & $(0.412)$ & $(0.343)$ & $(0.407)$ & $(0.227)$ & $(0.285)$ & $(0.260)$ \\
\hline \multirow[t]{2}{*}{$\begin{array}{c}\text { Patents } \\
\text { Intensity }\end{array}$} & 0.783 & & & 0.821 & & & 0.634 & & \\
\hline & $(0.575)$ & & & $(0.537)$ & & & $(0.622)$ & & \\
\hline \multirow[t]{2}{*}{$\begin{array}{c}\text { Total R\&D } \\
\text { Intensity }\end{array}$} & & $0.348 * * *$ & & & $0.380^{* * *}$ & & & $0.211^{* * *}$ & \\
\hline & & $(0.118)$ & & & $(0.128)$ & & & $(0.127)$ & \\
\hline \multirow[t]{2}{*}{$\begin{array}{c}\text { Business R\&D } \\
\text { Intensity }\end{array}$} & & & $0.228 * * *$ & & & $0.269 * *$ & & & $0.240 * *$ \\
\hline & & & $(0.110)$ & & & $(0.137)$ & & & $(0.125)$ \\
\hline \multirow[t]{2}{*}{$\begin{array}{c}\text { Government } \\
\text { R\&D Intensity }\end{array}$} & & & $0.167 * * *$ & & & $0.197^{* * *}$ & & & 0.123 \\
\hline & & & $(0.278)$ & & & $(0.201)$ & & & $(0.478)$ \\
\hline Observations & 99,957 & 93,304 & 92,659 & 56,386 & 52,538 & 52,297 & 32,853 & 30,738 & 30,380 \\
\hline $\begin{array}{c}\text { Multinational } \\
\text { firms } \\
\end{array}$ & 429 & 428 & 427 & 242 & 241 & 241 & 141 & 141 & 140 \\
\hline $\begin{array}{l}\text { NUTS2 } \\
\text { regions }\end{array}$ & 233 & 218 & 217 & 233 & 218 & 217 & 233 & 218 & 217 \\
\hline Log-likelihood & $-1,930.3$ & $-1,931.0$ & $-1,922.6$ & $-1,151.8$ & $-1,148.1$ & $-1,147.4$ & -591.9 & -592.6 & -584.0 \\
\hline Pseud-R2 & 0.175 & 0.162 & 0.163 & 0.131 & 0.120 & 0.120 & 0.230 & 0.220 & 0.225 \\
\hline
\end{tabular}

Notes: Figures shown are average probability elasticities. ${ }^{* * *}$ significant at the 1 per cent level, ${ }^{* *}$ significant at the 5 per cent level, * significant at the 10 per cent level. Standard errors shown in parentheses are clustered at country level. Explanatory variables are lagged with respect to the dependent variable by one period. Market potential, compensation per employee, agglomeration and patents intensity are in logs. Top university is a dummy variable. Unemployment rate, corporate tax rate, human capital and R\&D intensities are in percentage form and are evaluated at their mean value. European multinational firms are those with a parent in the following countries: Austria, Belgium, Bulgaria, Cyprus, Czech Republic, Germany, Denmark, Spain, Finland, France, United Kingdom, Gibraltar, Greece, Ireland, Israel, Isle of Man, Italy, Liechtenstein, Luxembourg, Switzerland, Monaco, the Netherlands, Norway, Poland, Portugal and Sweden. North American multinational firms are those with a parent in the US or Canada. 


\begin{tabular}{|c|c|c|c|c|c|c|c|c|c|}
\hline \multicolumn{10}{|c|}{ Table 6: Determinants of the Location Choice of R\&D Foreign Affiliates: Nested Logit Models } \\
\hline & \multicolumn{3}{|c|}{ All multinationals } & \multicolumn{3}{|c|}{ European multinationals } & \multicolumn{3}{|c|}{ North American multinationals } \\
\hline Variable & $(1)$ & $(2)$ & (3) & (4) & (5) & (6) & (7) & (8) & (9) \\
\hline \multirow[t]{2}{*}{$\begin{array}{c}\text { Market } \\
\text { Potential } \\
\end{array}$} & -0.072 & $0.668^{*}$ & 0.646 & -0.287 & 0.361 & 0.098 & 0.204 & 0.881 & 0.891 \\
\hline & (0.089) & $(0.064)$ & $(0.082)$ & $(0.125)$ & $(0.081)$ & $(0.114)$ & $(0.154)$ & (0.128) & $(0.146)$ \\
\hline \multirow[t]{2}{*}{$\begin{array}{l}\text { Compensation } \\
\text { Per Employee }\end{array}$} & $0.741^{*}$ & & 0.209 & 0.577 & & 0.363 & 1.997 & & 0.527 \\
\hline & (0.139) & & (0.119) & $(0.196)$ & & (0.168) & $(0.233)$ & & $(0.214)$ \\
\hline \multirow[t]{2}{*}{ Agglomeration } & $0.017^{* * *}$ & $0.035^{* * *}$ & $0.036 * * *$ & $0.011^{* * *}$ & $0.030 * * *$ & $0.032 * * *$ & $0.033^{* * *}$ & $0.035^{* * *}$ & $0.031^{* * *}$ \\
\hline & $(0.001)$ & $(0.001)$ & $(0.001)$ & $(0.001)$ & $(0.001)$ & $(0.001)$ & $(0.001)$ & $(0.001)$ & $(0.001)$ \\
\hline \multirow[t]{2}{*}{$\begin{array}{c}\text { Unemployment } \\
\text { Rate } \\
\end{array}$} & 0.432 & $-0.629 *$ & -0.435 & 0.083 & -0.868 & -0.729 & $1.808^{*}$ & -0.538 & -0.140 \\
\hline & $(0.010)$ & $(0.007)$ & (0.007) & $(0.015)$ & $(0.010)$ & $(0.012)$ & $(0.019)$ & (0.011) & $(0.012)$ \\
\hline \multirow[t]{2}{*}{$\begin{array}{c}\text { Corporate Tax } \\
\text { Rate } \\
\end{array}$} & 1.148 & 2.295 & 1.787 & 1.257 & 4.749 & 3.191 & 1.466 & -0.981 & -0.680 \\
\hline & $(0.011)$ & $(0.012)$ & $(0.012)$ & $(0.017)$ & $(0.018)$ & $(0.018)$ & $(0.021)$ & $(0.017)$ & $(0.018)$ \\
\hline \multirow[t]{2}{*}{ Human Capital } & $0.602 * * *$ & $0.567 * *$ & & $0.568 * *$ & $0.797 *$ & & $0.896^{* *}$ & 0.272 & \\
\hline & $(0.003)$ & $(0.002)$ & & $(0.004)$ & $(0.003)$ & & $(0.004)$ & $(0.003)$ & \\
\hline \multirow[t]{2}{*}{ Top University } & $0.764^{* * *}$ & $1.431^{* * *}$ & $1.575^{* * *}$ & $0.578 * * *$ & $1.112^{* * *}$ & $1.103^{* * *}$ & $1.635^{* * *}$ & $1.808^{* * *}$ & $1.794^{* * *}$ \\
\hline & $(0.123)$ & $(0.102)$ & $(0.106)$ & $(0.177)$ & $(0.131)$ & $(0.151)$ & $(0.222)$ & $(0.208)$ & $(0.223)$ \\
\hline \multirow[t]{2}{*}{$\begin{array}{c}\text { Patents } \\
\text { Intensity }\end{array}$} & $1.280 * * *$ & & & $1.011^{* * *}$ & & & $2.803 * * *$ & & \\
\hline & $(0.075)$ & & & $(0.116)$ & & & $(0.129)$ & & \\
\hline \multirow[t]{2}{*}{$\begin{array}{c}\text { Total R\&D } \\
\text { Intensity } \\
\end{array}$} & & $1.134^{* * *}$ & & & $1.192 * * *$ & & & $1.076 * * *$ & \\
\hline & & $(0.028)$ & & & $(0.040)$ & & & $(0.046)$ & \\
\hline \multirow[t]{2}{*}{$\begin{array}{c}\text { Business R\&D } \\
\text { Intensity } \\
\end{array}$} & & & $0.899 * * *$ & & & $1.111 * * *$ & & & $0.774 * * *$ \\
\hline & & & $(0.032)$ & & & $(0.046)$ & & & $(0.050)$ \\
\hline \multirow[t]{2}{*}{$\begin{array}{c}\text { Government } \\
\text { R\&D Intensity }\end{array}$} & & & $0.243^{* *}$ & & & $0.420 * *$ & & & 0.471 \\
\hline & & & $(0.091)$ & & & $(0.153)$ & & & $(0.125)$ \\
\hline \multicolumn{10}{|l|}{ IV Parameters } \\
\hline \multirow[t]{2}{*}{ South } & $0.147 * * *$ & $0.092^{* * *}$ & $0.114^{* * *}$ & $0.228 *$ & $0.125^{* * *}$ & $0.181^{* *}$ & $0.055^{*}$ & $0.048^{* *}$ & $0.050 * *$ \\
\hline & $(0.054)$ & $(0.024)$ & $(0.033)$ & $(0.123)$ & $(0.048)$ & $(0.079)$ & $(0.033)$ & $(0.019)$ & $(0.023)$ \\
\hline \multirow[t]{2}{*}{ UK and Ireland } & $0.621^{* * *}$ & $0.554^{* * *}$ & $0.561 * * *$ & $0.573^{* * *}$ & $0.479 * * *$ & $0.498 * * *$ & $0.694^{* * *}$ & $0.635^{* * *}$ & $0.628 * * *$ \\
\hline & $(0.065)$ & $(0.048)$ & $(0.053)$ & $(0.104)$ & $(0.065)$ & $(0.080)$ & $(0.101)$ & $(0.086)$ & $(0.088)$ \\
\hline \multirow[t]{2}{*}{ East } & $0.562 * * *$ & $0.590 * * *$ & $0.598 * * *$ & $0.628 * * *$ & $0.625^{* * *}$ & $0.648 * * *$ & $0.452 * * *$ & $0.511^{* * *}$ & $0.500 * * *$ \\
\hline & $(0.063)$ & $(0.051)$ & $(0.057)$ & $(0.102)$ & $(0.069)$ & $(0.089)$ & $(0.086)$ & $(0.095)$ & $(0.097)$ \\
\hline \multirow[t]{2}{*}{$\begin{array}{c}\text { Central and } \\
\text { North }\end{array}$} & $0.443^{* * *}$ & $0.254^{* * *}$ & $0.232 * * *$ & $0.548 * * *$ & $0.272 * * *$ & $0.292 * * *$ & $0.343 * * *$ & $0.241^{* * *}$ & $0.157 * *$ \\
\hline & $(0.081)$ & $(0.046)$ & $(0.046)$ & $(0.153)$ & $(0.073)$ & $(0.090)$ & $(0.119)$ & $(0.082)$ & $(0.071)$ \\
\hline Observations & 99,957 & 93,304 & 92,659 & 53,357 & 49,704 & 49,476 & 32,853 & 30,738 & 30,380 \\
\hline $\begin{array}{l}\text { Multinational } \\
\text { firms }\end{array}$ & 429 & 428 & 427 & 229 & 228 & 228 & 141 & 141 & 140 \\
\hline $\begin{array}{l}\text { NUTS2 } \\
\text { regions }\end{array}$ & 233 & 218 & 217 & 233 & 218 & 217 & 233 & 218 & 217 \\
\hline Log-likelihood & $-1,916.6$ & $-1,899.9$ & $-1,892.0$ & $-1,067.8$ & $-1,049.5$ & $-1,050.4$ & -575.3 & -578.5 & -568.5 \\
\hline $\begin{array}{c}\text { Chi2 for H0: } \\
\text { IIA holds } \\
\end{array}$ & $27.49 * * *$ & $62.27 * * *$ & $61.16^{* * *}$ & $8.50^{*}$ & $43.10^{* * *}$ & $40.37 * * *$ & $33.18 * * *$ & $28.14 * * *$ & $31.09 * * *$ \\
\hline
\end{tabular}


Notes: Figures shown are average probability elasticities. Standard errors shown in parentheses are clustered at country level. *** significant at the 1 per cent level, ** significant at the 5 per cent level, * significant at the 10 per cent level. Coefficients of IV parameters are point estimates. Explanatory variables are lagged with respect to the dependent variable by one period. Market potential, compensation per employee, agglomeration and patents intensity are in logs. Top university is a dummy variable. Unemployment rate, corporate tax rate, human capital and $R \& D$ intensities are in percentage form and are evaluated at their mean value. European multinational firms are those with a parent in the following countries: Austria, Belgium, Bulgaria, Cyprus, Czech Republic, Germany, Denmark, Spain, Finland, France, United Kingdom, Gibraltar, Greece, Ireland, Israel, Isle of Man, Italy, Liechtenstein, Luxembourg, Switzerland, Monaco, the Netherlands, Norway, Poland, Portugal and Sweden. North American multinational firms are those with a parent in the US or Canada.Chi2 is the statistics of the likelihood-ratio test on H0: IIA holds. 


\section{Appendix: Data and Data Sources}

Table A1: Variables Definitions and Data Sources

\begin{tabular}{|c|c|c|}
\hline Variables & Description & Source \\
\hline Market Potential & $\begin{array}{l}\text { Real GDP of the host region plus the sum of inverse distance-weighted real } \\
\text { GDP of all other regions. Distance is measured as the lorry travelling time } \\
\text { between the host region and all other regions. Average over 1995-2002. }\end{array}$ & $\begin{array}{l}\text { Cambridge } \\
\text { Econometrics } \\
\text { and own } \\
\text { calculations }\end{array}$ \\
\hline $\begin{array}{l}\text { Compensation per } \\
\text { Employee }\end{array}$ & Compensation per employee in constant prices, average over 1995-2002. & $\begin{array}{l}\text { Eurostat, } \\
\text { Regional } \\
\text { Statistics } \\
\text { database }\end{array}$ \\
\hline $\begin{array}{l}\text { R\&D } \\
\text { Agglomeration }\end{array}$ & $\begin{array}{l}\text { The total number of foreign } R \& D \text { firms located in each host region plus a } \\
\text { distance-weighted count of the foreign R\&D firms in all other regions up to } \\
2002 \text {. }\end{array}$ & $\begin{array}{l}\text { Bureau van } \\
\text { Dijk, Amadeus } \\
\text { database and } \\
\text { own calculation }\end{array}$ \\
\hline $\begin{array}{l}\text { Unemployment } \\
\text { Rate }\end{array}$ & Regional rate of unemployment, per cent. Average over 1995-2002. & $\begin{array}{l}\text { Cambridge } \\
\text { Econometrics }\end{array}$ \\
\hline $\begin{array}{l}\text { Corporate Tax } \\
\text { Rate }\end{array}$ & National top corporate tax rate, per cent. Average over 1995-2002. & $\begin{array}{l}\text { World Tax } \\
\text { Database, } \\
\text { Michigan } \\
\text { Business School }\end{array}$ \\
\hline Human Capital & $\begin{array}{l}\text { Percentage of the regional economically active population which have } \\
\text { attained tertiary education level (International Standard Classification of } \\
\text { Education). Average over 1998-2002. }\end{array}$ & $\begin{array}{l}\text { Eurostat, } \\
\text { Regional } \\
\text { Statistics } \\
\text { database }\end{array}$ \\
\hline Top University & $\begin{array}{l}\text { Dummy variable which is equal to one if the region has at least one university } \\
\text { ranked in the world top } 500 \text { universities and zero otherwise. }\end{array}$ & $\begin{array}{l}\text { The QS World } \\
\text { University } \\
\text { Rankings }\end{array}$ \\
\hline Patents Intensity & $\begin{array}{l}\text { Patent applications to the European Patent Office to real GDP ratio. Average } \\
\text { over 1999-2002. }\end{array}$ & $\begin{array}{l}\text { Eurostat, } \\
\text { Regional } \\
\text { Statistics } \\
\text { database and } \\
\text { own calculation }\end{array}$ \\
\hline $\begin{array}{l}\text { Business R\&D } \\
\text { Intensity }\end{array}$ & $\begin{array}{l}\text { R\&D expenditure in the business enterprise sector as a percentage of real } \\
\text { GDP in each region. Average over 1995-2002. }\end{array}$ & $\begin{array}{l}\text { Eurostat, } \\
\text { Regional } \\
\text { Statistics } \\
\text { database } \\
\end{array}$ \\
\hline $\begin{array}{l}\text { Government R\&D } \\
\text { intensity }\end{array}$ & $\begin{array}{l}\text { R\&D expenditure in the government sector as a percentage of real GDP in } \\
\text { each region. Average over 1995-2002. }\end{array}$ & $\begin{array}{l}\text { Eurostat, } \\
\text { Regional } \\
\text { Statistics } \\
\text { database }\end{array}$ \\
\hline $\begin{array}{l}\text { Total R\&D } \\
\text { Intensity }\end{array}$ & $\begin{array}{l}\text { Business R\&D and government } R \& D \text { expenditure as a percentage of real } \\
\text { GDP in each region. Average over } 1995-2002 \text {. }\end{array}$ & $\begin{array}{l}\text { Eurostat, } \\
\text { Regional } \\
\text { Statistics } \\
\text { database and } \\
\text { own calculation }\end{array}$ \\
\hline
\end{tabular}

